\title{
The motives attributed to trolls in metapragmatic comments on three Hungarian left-wing political blogs
}

\author{
Márton Petykó \\ Lancaster University
}

This paper investigates the linguistically marked motives that participants attribute to those they call trolls in 178 comment threads of three Hungarian left-wing political blogs. It is also concerned with how frequently these motives are mentioned and how they contribute to the discursive construction of trolling and trolls. Another goal of the paper is to examine whether the mainly emotional motives ascribed to trolls in the academic literature correspond with those that the participants attribute to the alleged trolls in the threads. The paper identifies five motives for trolling: emotional reasons, financial gain, political beliefs, being employed by Fidesz or the Hungarian government, and unspecified political affiliation. Depending on these motives, trolling and trolls are constructed in various ways. Furthermore, by suggesting that Fidesz or the Hungarian government employs trolls, the posters discursively construct Fidesz as an autocratic and corrupt state party that tries to manipulate the public.

Keywords: trolling, computer-mediated communication, blog, Hungarian, politics, motivation, mental state attribution, metapragmatic comment

\section{Introduction}

This corpus-based study investigates a prominent phenomenon of computermediated communication (CMC): trolling. It aims to answer four questions:

1. What linguistically marked motives do the participants attribute to those they call trolls in 178 comment threads of three Hungarian left-wing political blogs, B1, Örülünk, Vincent?, and Varánusz?

2. To what extent do the motives ascribed to trolls in the academic literature correspond with those that the participants attribute to the alleged trolls in these threads? 
3. Depending on these motives, how are trolling and trolls constructed in the threads?

4. How frequently are these motives mentioned in the threads?

The study further develops a corpus-based analytical framework for the study of metapragmatic comments, focusing on linguistically marked mental state attribution and the construction of folk concepts associated with discursive behaviours, such as trolling. The analysis deals with 123 metapragmatic comments taken from the above-mentioned 178 threads. In these comments, the posters call other participants trolls or identify comments as trolling and also discuss the reasons why the alleged trolls might be trolling.

This study can be situated within the fields of corpus-based discourse analysis (Baker 2006) and pragmatics (Culpeper and Hardaker 2016). Beyond trolling, the paper has relevance to the pragmatics of CMC (Herring, Stein, and Virtanen 2013) and within that, to the study of metapragmatic comments in CMC (Tanskanen 2007).

\section{Trolling in computer-mediated communication}

Academic interest in trolling has grown remarkably in several fields, including linguistics (Hardaker 2010), media and communication studies (Fichman and Sanfilippo 2015), psychology (Buckels et al. 2014), and computer science (Ortega et al. 2012). However, despite its expanding media coverage and its relevance to legislation, trolling has several under-researched aspects (Hardaker 2015). This paper attempts to contribute to the study of three such areas. These are (1) trolling in online political discourse, which is only discussed by Özsoy (2015), (2) trolling in non-English interactions, which is covered only in papers written in languages other than English (Petykó 2013), and (3) the assumed motives attributed to trolls, which are discussed in detail only in Shachaf and Hara (2010) and Fichman and Sanfilippo (2015).

There are numerous academic definitions of 'trolling' but these tend to be partial, overlapping, contradictory, decontextualized, and intuitive (Hardaker 2013). 'Trolling' is also used as an umbrella term for describing various behaviours that are negatively marked (Binns 2012), non-normative (Herring et al. 2002), antisocial (Buckels et al. 2014), or malicious (Ortega et al. 2012). Moreover, whilst trolling is frequently discussed in relation to flaming (Cheng et al. 2015), cyberbullying (Galán-García et al. 2014), and online vandalism (Shachaf and Hara 2010), the exact nature of the relationship between trolling and these behaviours remains unclear.

Considering these issues, I agree with McCosker (2014) that 'trolling' and 'troll' cannot be used as objective theoretical concepts since they lack well-established 
definitions that could be used for analysing texts without methodological problems. Thus, I do not employ 'trolling' and 'troll' as theoretical terms but I approach them as metapragmatic labels (Hardaker 2015) that refer to folk concepts that participants use and reconstruct as they interpret others' discursive behaviour in the ongoing online interaction.

The term 'trolling' is usually described as a set of goal-driven behaviours (Hardaker 2013), while 'troll' is deemed a behaviour-based identity (Golder and Donath 2004). Thus, the two main aspects of trolling covered in the literature are the trolls' alleged goals and the actions thought to constitute trolling. The most often mentioned goals ascribed to trolls are:

1. attracting other users' full attention (Hardaker 2010)

2. triggering intense unpleasant emotional reactions, such as annoyance or anger in others (Thacker and Griffiths 2012)

3. eliciting potentially offensive responses from others, which themselves can provoke further hurtful responses (Morrissey 2010)

4. causing, perpetuating or escalating conflict (Galán-García et al. 2014)

5. disrupting the interaction (Binns 2012)

6. deceiving or manipulating others (Donath 1999).

These goals show that trolls are believed to attempt to negatively influence other users' attention, emotions, beliefs, actions, interpersonal relations, and the online interaction. The literature also discusses the discursive actions perceived as trolling. The most often mentioned ones are:

1. repeating the same utterance (Shachaf and Hara 2010)

2. posting irrelevant or meaningless information (Morrissey 2010)

3. posting misleading or factually incorrect information (Hardaker 2010)

4. disseminating bad and/or dangerous advice (Donath 1999)

5. ignoring, despising, rejecting, or attacking the core values of the interaction (Utz 2005)

6. (hypo)criticising others often for an offence of which the critic was also guilty (Hardaker 2013)

7. directly insulting, threatening or otherwise attacking others (Herring et al. 2002).

Although only one source is cited after each goal and action, the cited studies mostly agree on what aims and actions characterise trolling. However, these studies focus on different platforms and cover a time frame from 1999 to 2015. The most often analysed platform is Usenet (Hardaker 2015). However, other platforms, such as an online feminist forum (Herring et al. 2002), Hebrew Wikipedia pages (Shachaf and Hara 2010), online games (Thacker and Griffiths 2012), corporate 
websites (Binns 2012), British online newspapers (Hopkinson 2013), and Twitter (Galán-García et al. 2014) have also been studied. Political blogs have not been analysed but the fact that similar goals and actions have been observed on different platforms suggests that the main goals and actions associated with trolling are relatively platform-independent. Similarly, the literature does not suggest that trolling has been radically changed in the past two decades. However, one should not reject the possibility of historical change in trolling as no study has focused on this issue.

Herring et al. (2002) and Shachaf and Hara (2010) claim that the essence of trolling is the violation of interactional norms. To understand this statement, we need to consider the nature of interactional norms in CMC. Following Postmes et al. (2000), it is worth distinguishing the explicitly codified norms of CMC from the implicit, (inter)subjective ones. Explicitly codified norms are predefined rules that specify the acceptable or unacceptable behaviour in an interaction. These rules are created by the owner, administrator, or moderator of the website where the interaction takes place, and the users often need to formally accept those (Binns 2012). However, normally, not all users agree with, respect, or even read these rules.

Beyond the explicit rules, all participants have beliefs about how one should act in a computer-mediated interaction. Participants use these beliefs to decide whether an utterance is appropriate from their own perspective. These norms are implicit and subjective but the participants may decide to discuss and negotiate them with one another. Therefore, these individual beliefs may become group norms (Hardaker 2013). Explicit rules may affect these individual beliefs and shared group norms but equally, the two sets of norms can be different or contradictory.

The diversity of norms suggests that the above-mentioned actions do not constitute an exhaustive list of those associated with trolling as depending on what actions the different participants deem inappropriate, the actions considered to constitute trolling may vary across interactions and even across individuals (Hardaker 2013).

Although the motives for trolling are also mentioned in the literature, most studies do not attempt to empirically examine them (Hopkinson 2013). The only exceptions are Shachaf and Hara (2010) and Fichman and Sanfilippo (2015) who used interviews and online questionnaires to examine what 15 Israeli Wikipedia editors and 100 US Midwestern university students think about the motives behind trolling. However, as these studies can only summarize what their respondents think about the trolls' motives in general, they are unable to provide any evidence on the motives that the respondents attribute to assumed trolls when engaging in actual online interactions. This is a clear gap in the literature, which this study addresses.

Trolling is usually approached as an emotionally motivated individual behaviour. The most frequently mentioned motive is that trolls engage in this behaviour because they simply enjoy it or its consequences, including the attention and reactions they receive and the harm their behaviour causes (Hardaker 2010). Further 
emotional motives are also mentioned, such as boredom (Baker 2001), a desire for control and self-empowerment, hate towards specific participants, hostility to the purpose of the interaction (Herring et al. 2002), a need for attention or achievement, revenge (Shachaf and Hara 2010), loneliness, malevolence, and curiosity (Fichman and Sanfilippo 2015. It is also suggested that trolls can be motivated by specific political goals and ideologies (Özsoy 2015). A key aim of this study is to examine whether the above-mentioned motives correspond with those that the participants attribute to the alleged trolls in the analysed comments.

\section{3. 'Trolling' and 'troll' as metapragmatic labels}

Approaching 'trolling' and 'troll' as metapragmatic labels, i.e. "lexical expressions that denote cognitive and cultural models associated with how (verbal) human communication is conceptualized" (Verschueren 1999, 196), entails that calling someone a troll or describing comments as trolling are metapragmatic comments. I consider 'metapragmatic comments' to be those utterances or utterance parts in which one explicitly refers to others' or one's own discursive actions (Hübler 2011).

The study of metapragmatic comments is a way of analysing the folk concepts that the participants use to interpret discursive actions (Verschueren 2000), since a common purpose of metapragmatic comments is to interpret and evaluate others' discursive behaviour (Hübler 2011). Consequently, such comments are strongly related to 'social cognition', a set of the cognitive abilities we use and the mental processes we perform when interpreting and predicting human behaviour and interpersonal relations (Langlotz 2010).

A key component of social cognition is 'inference', which denotes the cognitive ability of drawing conclusions from perceived actions, and it also involves the cognitive processes by which humans make these judgements (Noveck 2010).

Some of these conclusions relate to the assumed mental states of the person who carried out those actions. All mentally healthy adults have the ability to attribute mental states, such as beliefs, intentions and motives as well as cognitive processes to themselves and others (Balconi 2010). That is, we consider others' behaviour to indicate their mental states and we make inferences from their behaviour to construct assumptions on their mental states, which we then use to explain their behaviour. This ability and its use are called 'Theory of Mind' (ToM) (Tomasello et al. 2005) or 'mental state attribution' (Lockard 2014).

Therefore, I treat 'mental states' as folk psychological concepts that the participants of (online) interactions attribute to others to explain their behaviour (Haugh and Jaszczolt 2012). Within mental states, I focus on 'motives', which I define as assumed mental states in which an agent voluntarily carries out an action because 
of specific internal and external reasons (Wright 2016). The internal reasons refer to the agent's own mental states including beliefs and emotions, while the external reasons are factors of the agent's perceived environment.

I deem 'mental state attribution' to be a cognitive process by means of which participants form a belief that other participants perform certain actions because they possess particular mental states (Lockard 2014). Within mental state attribution, I focus on 'linguistically marked mental state attribution'. This involves those cases when participants use language to express the mental states they attribute to others. While mental state attribution is a directly not observable cognitive process, linguistically marked mental state attribution can be examined by analysing metapragmatic comments.

As mentioned earlier, 'troll' can be considered a behaviour-based identity. Thus, when participants call others trolls, they recognise them as members of a troll category and create their troll identity based on their behaviour, including their perceived actions, goals, and motives. I define identity as a set of characteristics associated with an individual that relate this individual to other similar individuals while also distinguishing him/her from other dissimilar individuals (Jenkins 2014,6 ). This paper argues that the metapragmatic comments in which participants call others trolls and also specify the motives of those they call trolls are discursive identity-building devices through which the participants shape the alleged trolls' identity in various ways, depending on what motives they attribute to them. The analysis also uses the term 'conceptual frame' when analysing the metapragmatic comments. 'Conceptual frame' refers to an organised set of interrelated concepts that forms a specific element of our human knowledge of the world (Cienki 2007).

\section{Data and method}

\subsection{Data collection}

The corpus consists of 178 threads of three left-wing Hungarian political blogs, $B 1$ (http://b1.blog.hu/), Örülünk, Vincent? (ÖV) (http://orulunkvincent.blog.hu/), and Varánusz (http://varanus.blog.hu/). In this paper, a 'thread' refers to one blog post and its subsequent comments. These 178 threads therefore include 178 blog posts and their 55,276 comments. The threads were selected based on two criteria:

1. The thread had to be published on B1, ÖV, or Varánusz between 1 January and 31 December 2015.

2. The thread had to include at least one 'troll comment' in which a participant called at least one other participant a troll and/or described at least one 
comment as an act of trolling at least once. That is, at least one participant had to use a Hungarian word form of the lexeme TROLL, such as trollt 'troll-ACC' or trollkodás 'trolling' to refer to another participant or comment.

Data collection included the following steps:

1. A list of 50 Hungarian political blogs active in 2015 was compiled. I considered a blog to be any website appearing on a blog hosting platform, e.g. blog.hu and/ or that called itself a blog. They were deemed to be active in 2015 if at least one post was published between 1 January and 31 December 2015. Finally, I classified political blogs as those whose main topic is politics, i.e. the acquisition, distribution and practice of power in human communities, societies and states. Four sources for collection were used:

a. Goldenblog contest. This was an annual Hungarian blog contest, organised by hvg.hu, the online version of Heti Világgazdaság (HVG) 'Weekly World Economy', a weekly economic and political magazine. I considered the blogs shortlisted in two categories: Hírblogok 'News blogs' $(2011,2012)$ and Közélet 'Public Sphere' $(2013,2014){ }^{1}$

b. Lap.hu. The largest Hungarian aggregator website. I looked at those blogs that appeared on http://politikusblog.lap.hu. ${ }^{2}$

c. Google search. The search terms were politikai blog 'political blog', "politikai blog" 'political blog as an exact term' and politika blog 'politics blog'.

d. The political blogs recommended on those already collected were also considered.

2. I selected those 27 blogs that identified themselves as left-wing political blogs.

3. I gathered all those threads from these blogs that included at least one 'troll comment'. I manually searched all 3,181 threads for the troll character string, and found 289 relevant threads. Then I saved each thread in a separate txt file.

4. I selected the first three blogs, B1, ÖV and Varánusz, since these had the highest number of qualifying threads.

B1, Örülünk, Vincent, and Varánusz are very similar blogs. All were established in 2009 , they have at least two permanent authors and none are affiliated with a political party or institute. They can be considered opposition blogs since Hungary has had a right-wing coalition government since the 2010 elections and these blogs usually criticise the government, governmental policies, the governing parties, and their key figures, including Viktor Orbán, the Prime Minister. The main governing party

1. These are available at http://goldenblog.hu/. (Date of access: 1 March 2016)

2. (Date of access: 1 March 2016) 
is Fidesz - Magyar Polgári Szövetség ('Fidesz - Hungarian Civic Alliance’), a national conservative party, while their coalition partner is the Kereszténydemokrata Néppárt or KDNP ('Christian Democratic People’s Party'), a conservative Christian party. As the government controls the state media and dominates a considerable part of the private media in Hungary, political blogs have become important arenas where liberal and left-wing political opinions can be published.

The moderation policy of each blog slightly differs. $B 1$ does not have an explicit moderation policy and it is not actively moderated. $O$ V has an explicit moderation policy: namely, posters can delete comments in the thread of their own blog posts. Furthermore, the permanent authors actively moderate the threads by deleting comments or banning users. Several comments from a moderator show that the main aim of moderation is to delete off-topic comments that could distract the discussion from its initial topic. Finally, Varánusz does not have an explicit moderation policy but it is actively moderated. Several comments from the moderator

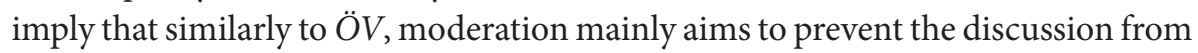
going off-topic.

\subsection{Corpus and data analysis}

Table 1 includes the number of blog posts, comments, and words in the corpus.

Table 1. The number of blog posts, comments, and words in the corpus

\begin{tabular}{lrrrr}
\hline & \multicolumn{1}{c}{ B1 } & \multicolumn{1}{c}{ ÖV } & \multicolumn{1}{c}{ Varánusz } & \multicolumn{1}{c}{ Overall } \\
\hline Blog posts & 61 & 49 & 68 & 178 \\
& $(34.3 \%)$ & $(27.5 \%)$ & $(38.2 \%)$ & $(100 \%)$ \\
Comments & 5,448 & 9,497 & 40,331 & 55,276 \\
& $(9.9 \%)$ & $(17.1 \%)$ & $(73 \%)$ & $(100 \%)$ \\
Words & 326,739 & 616,761 & $1,492,984$ & $2,436,484$ \\
& $(13.4 \%)$ & $(25.3 \%)$ & $(61.3 \%)$ & $(100 \%)$ \\
\hline
\end{tabular}

The majority of the data comes from Varánusz as $73 \%$ of the comments and $61 \%$ of the words were published on this blog. However, word count can be a flawed size measurement for online interactions as participants frequently quote earlier utterances.

Data analysis included a corpus-based qualitative-interpretative analysis and a quantitative analysis. It consisted of the following steps:

1. Using the concordance lines of the search term ${ }^{*}$ troll $^{\star}$ generated by the software package \#LancsBox (Brezina, McEnery and Wattam 2015), I selected the troll comments. 
2. Using the same concordance lines, I selected those troll comments in which the assumed motives for trolling were discussed (hereon referred to as 'troll motive comments'). The first two steps were carried out manually as it was impossible to identify the troll (motive) comments without reading and interpreting the comments. This is because the fact that the word troll occurs in a comment does not necessarily mean that the participant who uses the word indeed calls someone a troll. Similarly, only because a potentially motive-related word occurs in a troll comment, one cannot conclude that a motive for trolling is indeed specified. Consequently, the researcher needs to look at the concordance lines and decide whether those comments in which the word troll occurs are troll (motive) comments.

3. I identified the linguistically marked motives that the participants attributed to those they called trolls and created a taxonomy from them.

4. I compared the motives identified in the troll motive comments with those covered in the academic literature.

5. I described how trolling and trolls are constructed in the troll motive comments, depending on the motives attributed to the trolls.

6. To determine how often the participants explicitly attribute the identified motives to the alleged trolls, I used the motives as descriptive categories and manually provided each troll motive comment with motive-related annotations. The units of annotation were the comments themselves and not particular sentences. I made this decision as the qualitative analysis demonstrated that we need to examine the whole comment to identify the motive(s) attributed to assumed trolls.

7. To make this discursive-pragmatic annotation process more transparent and systematic, I identified those recurring sequences of words (n-grams) that clearly indicate an attributed motive on their own. This was done through the 'Clusters/N-Grams' function in the corpus analysis package AntConc (Anthony 2016). I chose to collect n-grams as they are frequently used for analysing the semantic and grammatical behaviour of a word based on its immediate context (Greaves and Warren 2010). The search term was ${ }^{\star}$ troll $^{\star 3}$ and I focused on 2-grams, 3-grams and 4-grams, i.e. sequences that include two, three or four words.

8. I summarised the quantitative results of the annotation, focusing on the number of those comments in which the different motives occurred.

3. The asterisk $\left({ }^{\star}\right)$ wildcard denotes 'zero or more characters'. Thus, a search for ${ }^{\star}$ troll $^{\star}$ will retrieve any character string between white spaces that includes troll, such as trollok ('trolls'), bértroll ('paid troll') and kontrollált ('controlled'). Kontrollált is a false hit but it can be easily ignored. 


\section{A taxonomy of the motives attributed to trolls}

Table 2 includes the number of comments, troll comments, and troll motive comments. The percentages in round brackets denote how the numbers within the same row relate to one another. For instance, (9.9\%) in the first column means that $9.9 \%$ of all collected comments come from B1. The percentages within square brackets show how the numbers within the same column relate to one another. For instance, [0.2\%] in the last column demonstrates that the assumed motives for trolling are discussed in $0.2 \%$ of all comments.

Table 2. The number of all comments, troll comments, and troll motive comments in the corpus

\begin{tabular}{lrrrr}
\hline & \multicolumn{1}{c}{ B1 } & \multicolumn{1}{c}{ ÖV } & \multicolumn{1}{c}{ Varánusz } & Overall \\
\hline Comments & 5,448 & 9,497 & 40,331 & 55,276 \\
& $(9.9 \%)$ & $(17.1 \%)$ & $(73 \%)$ & $(100 \%)$ \\
Troll comments & {$[100 \%]$} & {$[100 \%]$} & {$[100 \%]$} & {$[100 \%]$} \\
& 126 & 113 & 217 & 456 \\
Troll motive & {$[27.6 \%)$} & $(24.8 \%)$ & $(47.6 \%)$ & $(100 \%)$ \\
comments & $6.3 \%]$ & {$[1.2 \%]$} & {$[0.5 \%]$} & {$[0.8 \%]$} \\
& $(52 \%)$ & $17.8 \%)$ & $(34.2 \%)$ & $(100 \%)$ \\
& {$[1.2 \%]$} & {$[0.2 \%]$} & {$[0.1 \%]$} & {$[0.2 \%]$} \\
\hline
\end{tabular}

As shown in the bottom cell in the last column, only $0.2 \%$ (123) of all comments are troll motive comments. The analysis focuses on these. The first and the last cells in the first column also demonstrate that although only $9.9 \%$ of all comments come from $B 1,52 \%$ of the troll motive comments belong to this blog. On the other hand, while $73 \%$ of all comments were published on Varánusz (third column, first row), only $34.2 \%$ of the troll motive comments come from this blog (third column, last row).

This difference was caused by a single participant on $B 1$ who frequently used the motive-related expressions fidesztroll 'Fidesz troll' and fizetett fidesztroll 'paid Fidesz troll' and consequently, his/her comments were deemed troll motive comments. This shows that since only a small minority of the posters call others trolls, the individual habits of those who do so can have a major impact on the number of troll (motive) comments on a blog.

Five recurring motives for trolling emerged during the qualitative analysis of these 123 comments. These assumed motives are (1) emotional reasons, (2) financial gain, (3) political beliefs, (4) being employed by Fidesz or the Hungarian government, and (5) unspecified political affiliation. These motives are discussed next. 


\subsection{Assumed motive for trolling (1): Emotional reasons}

The first motive attributed to the trolls includes various emotional reasons, such as joy, loneliness and envy. Thus, participants assume that the alleged trolls are trolling because they enjoy trolling, it decreases their loneliness, or they try to handle their envy this way.

(1) [Varánusz 13012015]

ciccmicc, vagy nagyon megsütötte buksidat a napocska, vagy endorfin termelése okán trollkodsz... ezért sem eröltetem a kettönk közti kommunikációt oly nagyon...

'pussycat, the sun has really burnt your little head, or you are trolling for producing endorphin... that's why I'm not really forcing the communication between us...'

In Example (1), the poster proposes two alternatives to explain why the addressee ${ }^{5}$ is trolling. According to the first one, he is trolling because he is simply silly. The poster uses the euphemistic and slightly sarcastic expression nagyon megsütötte buksidat a napocska ('the sun has really burnt your little head', suggestive of heat stroke) to indicate that he considers the other participant to be cognitively impaired. The alternative is that the addressee is trolling because it makes him happy, as implied by the clause endorphin termelödése okán trollkodsz ('you are trolling for producing endorphin').

(2) [ÖV 12012015]

Tényleg troll vagy. Magányos vagy? vagy munkában sikeres, de bántottak kiskorodban? Hallgatunk, és nem nevetünk ki.

'You are really a troll. Are you lonely? or successful in job but were bullied as a child? We are listening and won't laugh at you.'

(3) [Varánusz 26042015]

[User name] is valami péniszirigység miatt jár ide alázni magát, ha már írói vénája ennyire halovány. Nem megy a pici blogja, hát trollkodik a lölköm...

'[User name] comes here to humiliate himself because of some penis envy if his literary talent is so weak anyway. His little blog isn't too successful so he is trolling...'

4. The information in square brackets shows when and on which blog the comment was published. For instance, Example (1) was published on Varánusz on 13 January 2015. The names have been anonymized. Otherwise, the comments have not been changed.

5. As the troll motive comments always reply to the alleged trolls' comments, there is an interactional relationship between those who call others trolls and those who are called trolls. Therefore, I call the addressed trolls 'addressees' while 'poster' refers to those who posted the troll motive comments. 
Example (2) illustrates two further emotional reasons. The first is loneliness, while the second is a childhood trauma that has had a long-term impact on the troll's personality and behaviour. In Example (3), it is suggested that the participant is trolling because his own blog is not successful and thus, he is jealous of the highly popular Varánusz blog.

Emotional reasons constitute the dominant motive for trolling in the literature. Thus, it is not surprising that they can also be observed in the analysed threads. When posters suggest this motive, trolling is constructed as an emotionally motivated, individual, unorganised, and spontaneous behaviour while trolls are portrayed as miserable individuals with emotional, mental health-related, and social problems.

\subsection{Assumed motive for trolling (2): Financial gain}

A key assumed motive for trolling is financial gain. The participants indicate in several comments that they believe that certain participants are trolling because they are paid for it.

(4) [Varánusz 27012015]

Azért mert pénzért trollkodsz.

'Because you are trolling for money.'

(5) [B1 13112015]

Ej de szánalmasan trollkodsz bértroll. Most hogy elmenekültél a másik blogból a kérdések elöl, még szánalmasabban tolod te kollaboráns bünözö.

'Wow you're trolling really pathetically wage troll. Now that you've fled from the other blog to avoid the questions, you are doing it even more pathetically you collaborating criminal.'

(6) [ÖV 29062015]

kár volt beleakaszkodni a halott zsidó terroristába, ez a -legalább-27. nick-je, most majd belép egy másikkal vagy eloldalgott... kavart egyet szokása szerint és most megy a napidijáért, troll a drágám

'there was no sense in picking a fight with the dead Jewish terrorist, this is his -at least- $27^{\text {th }}$ nickname, now he will log in with another one or he has sneaked away...he made some trouble as usual and now he is going to get his daily wage, this cutie is a troll'

In Examples (4)-(6), the posters use different linguistic tools to indicate their belief that the main motive behind trolling is financial gain. Example (4) is the most transparent as the Hungarian -ért ('for') suffix clearly indicates that the poster refers to pénz ('money') as the reason why the addressee is trolling. 
In Examples (5) and (6), the idea that trolls are being paid is expressed in different ways. In Example (5), the addressee is called a bértroll ('wage troll'). The compound word bértroll and especially bér- ('wage') as the first element of this compound evokes bérmunkás ('wage worker'), which usually refers to daily or weekly paid, unskilled physical workers of low prestige. Thus, bértroll not only indicates that the alleged troll receives money for his activity but also implies that he is unskilled, of low prestige, and employed by someone. Bértroll can also evoke bértapsoló ('wage applauder'), an informal pejorative word, which refers to those who are allegedly paid to cheer and clap at various political events.

In Example (6), the poster mockingly assumes that the indirectly addressed troll will receive his daily wage for his activity in the ongoing interaction. The compound word napidij ('daily wage') evokes a rather similar conceptual frame to that of bértroll. With this word, the poster may imply that the alleged troll is an unskilled and consequently low-paid employee of low prestige. In sum, both Examples (5) and (6) suggest that the financial gain that trolls are believed to achieve with their behaviour is rather trifling.

The examples also demonstrate that the belief in paid trolling is expressed in the comment threads of all three blogs. This is discussed in more detail in Section 6 . The alleged trolls are called fizetett trollok ('paid trolls') as well in other troll motive comments. However, as illustrated in Examples (4)-(6), the posters do not necessarily name those whom they believe to financially support the alleged trolls and they do not clarify either why one would pay others to keep trolling on these blogs.

Financial gain is a prominent assumed motive for trolling in the comments. However, the literature does not cover this motive. In these comments, trolling is constructed as a financially motivated but not centrally organised individual activity. Trolls are represented as rational but immoral, and dishonest individuals, who accept money for a widely disapproved activity, namely trolling, but would never admit that they are only trolling for money.

\subsection{Assumed motive for trolling (3): Political beliefs}

In Examples (7) and (8), the posters suggest that certain participants are trolling since they are keen supporters of Fidesz and/or the Hungarian government. In other cases, such as in Examples (9) and (10), the alleged trolls are believed to be individuals with strong right-wing views, who do not necessarily support the government or the governing parties but definitely oppose the left-wing ideologies these blogs follow. Thus, the main assumed motive for trolling here is a strong right-wing political belief that contradicts the political ideas the investigated blogs promote. 
(7) [B1 05022015]

Ja, Vitya választást nyert. Az eredménye az, amit felsoroltam fönt. És erre az eredményre nyáladzik az egybites szektás narancstroll. :-)

'Yeah, Vitya has won the elections. Its outcome is what I listed above. And the one-bit sectarian orange troll is drooling over this outcome. :-)'

[Vitya is a highly informal and mocking nickname for Viktor Orbán, the Hungarian Prime Minister. Egybites ('one-bit') means silly and orange is the official colour and (former) symbol of Fidesz.]

(8) [B1 07062015]

Ilyen gazdag szókincsel és ennyi szeretet, empátiát sugárzó hozzászólással csak valami KDNP-hittérítö lehetsz, vagy valami agymosott fidióta troll.

'With such a rich vocabulary and with so many comments radiating love and empathy, you must be only some KDNP missionary or some brainwashed 'fidiot' [fidióta is a blend word that combines fidesz(es) and idióta 'idiot'] troll.'

(9) [ÖV 01052015]

A egy széljobbos troll

'A is a far-right troll'

(10) [Varánusz 05022015]

"a közhelyes propaganda szöveget egzakt tényekkel lehet megtorpedózni” Na ne, ez te sem gondolhatod komolyan. Egy hithü fanatikusnak tényeket? Meg sem hallja, nemhogy rést ütne a páncélján. A másik indokod inkább elfogadható, de ehhez meg nem kell a troll.

" "the banal propaganda text can be torpedoed by exact facts" No way, you cannot be serious about this. Facts for a faithful fanatic? He won't even hear them, let alone would let them breach his armour. Your other argument is more acceptable, but we don't need the troll for that.'

Apart from Example (9), in which the addressee is simply called a far-right troll, the alleged trolls are constructed as intolerant and ignorant religious fanatics. In Example (7), the pejorative egybites ('one-bit, i.e. silly') and szektás ('sectarian') are used to construct the addressee as a close-minded religious bigot with limited mental capacity. As orange is the official Fidesz colour and (former) symbol, the compound narancstroll ('orange troll') clearly implies in this context that the sect the troll is believed to belong to consists of the most enthusiastic Fidesz supporters.

In Example (8), the poster offers two equally pejorative identities to the addressee. According to the first one, he is a KDNP missionary. KDNP is a Christian conservative party that is highly rejected and often considered only an insignificant satellite party of Fidesz on these left-wing blogs as most posters believe that KDNP lacks public support and would not be a parliamentary party without the support of Fidesz. This label therefore also evokes the above-mentioned pejorative conceptual 
frame of religious fanaticism. The other alternative is that the addressee is a brainwashed 'fidiot' troll. The adjectives agymosott ('brainwashed') and fidióta, a blend that combines fidesz(es) ('Fidesz (supporter)') and idióta ('idiot'), emphasize that the addressee is thought to be closed-minded, unable to think independently, and willing to believe everything the main governing party says.

In Example (10), the poster does not explicitly associate the assumed troll with the Hungarian government or the governing parties but refers to him as a hithü fanatikus ('faithful fanatic') employing the conceptual frame of religious fanaticism to highlight the extremism and bigotry of the alleged troll's assumed political beliefs. The expression hithü fanatikus suggests that the troll, similarly to religious fanatics, is so deeply attached to his beliefs that he is unable to critically assess them or accept that other political beliefs exist and at least have some merit. In the next sentence, the poster also implies with the metaphorical expression rést ütne a páncélján ('would breach his armour') that the alleged troll completely ignores the facts.

Political beliefs as a motive for trolling are mentioned in Özsoy (2015) but are not discussed in much detail. When posters assume that others are trolling due to their political beliefs, trolling is constructed as an ideologically motivated individual activity and trolls are depicted as irrational political fanatics, who are unable to engage in rational debate.

\subsection{Assumed motive for trolling (4): Being employed}

by Fidesz or the government

The fourth motive is that trolls are trolling on these left-wing blogs because Fidesz or the Hungarian government employs them and has ordered them to do so. The key difference between this motive and the second one is that in this case, the participants explicitly specify who employs the trolls. However, no direct or indirect evidence supports these claims either on these blogs or outside them.

(11) [B1 22072015]

Mi van ostoba fizetett fidesztroll? Június 1.-ével álltál munkába a tolvaj fidesznél? 'What's up silly paid Fidesz troll? Did you start working at the thief Fidesz on 1 June?'

(12) [ÖV 28042015]

Látom most neveztek ki a Miniszterelnökségen ügyeletes trollkodónak. (március 5)

'I can see that you have been appointed now as troller on duty at the Prime Minister's Cabinet Office. (5 March)' 
In Example (11), the poster calls the addressee an ostoba fizetett fidesztroll ('silly paid Fidesz troll'). With this construction, he implies that the addressee not only receives casual payment from Fidesz for his activity, but that he is also employed by them. Thus, trolling is constructed as a job in this comment.

In Example (12), the addressee is called not simply a troll but an ügyeletes trollkodó ('troll on duty'), who has been appointed to this position at the Prime Minister's Cabinet Office, which is a key ministry in the Hungarian government. Thus, this comment constructs being a troll as an actual position in a governmental institution of significant executive power, with direct contact to the Prime Minister of Hungary.

The assumed motive that trolls are employed by Fidesz or the government has four explicitly discussed recurring components. As part of their employment, Fidesz or the Hungarian government (1) sends the trolls to these left-wing blogs, (2) tells them how to troll, (3) financially supports their activity and (4) also trains them. These are illustrated in Examples (13)-(17) below:

(13) [Varánusz 08042015]

Mi sem bizonyítja jobban az orbáni rendszer erózióját, hogy egyre primitivebb gondolkodású egyedeket küldenek trollkodni.

'Nothing proves the erosion of the Orbán system better than the fact that they are sending individuals with more and more primitive thinking to troll.'

The poster claims in Example (13) that as part of the so-called Orbán system, trolls are being sent to the Varánusz blog and possibly to other left-wing blogs. This implies that it is not the trolls who decide where they will be trolling but someone else. Furthermore, the construction orbáni rendszer ('Orbán system') evokes Kádár-rendszer ('Kádár system'), which refers to the autocratic communist era between 1956 and 1989 when Hungary was a one-party state, de facto led by János Kádár, the General Secretary of the Hungarian Socialist Worker's Party. Thus, orbáni rendszer depicts the current Hungarian government as similar to the rejected Kádár system and consequently, trolls are constructed as collaborators who serve an autocratic political system.

(14) [B1 05092015]

A gazdád ezt mondta az eligazitáson balfasz fidesztroll, hogy ezt kell hazudni a blogokon? Mellesleg komunistaszombat van a fidesz pártszékházban?

'Did your master say at the briefing, dumbfuck Fidesz troll, that you had to lie this on the blogs? By the way, is it Communist Saturday in the Fidesz party headquarters?'

Example (14) demonstrates that trolls are believed to receive instructions not only on where but also on how to troll. The poster sarcastically implies that the addressee 
attended a briefing in the Fidesz party headquarters where he was instructed to spread lies on different blogs. The word gazdád ('your master') suggests that the person who gave the instructions on how to troll has full authority over the assumed troll and consequently, the troll himself only follows orders. Similarly to Example (13), the compound kommunistaszombat ('Communist Saturday') evokes the communist era of Hungary when following the Soviet practice, workers were required to work "voluntarily", i.e. for free, on certain Saturdays "to build the socialist society". With this pejorative construction, Fidesz is depicted as a communist state party similar to the Hungarian Socialist Worker's Party, the only party in Hungary between 1956 and 1989, while the addressed troll is constructed as a regular party worker who needs to work for the party even on Saturdays.

(15) [B1 05092015]

Muhaha! Gyenge próbálkozás, elötted ezt a viccet már legalább 5 fidesztroll ellötte. De az ilyen hozzászólásokért is fizet a fideszes agitprop osztály, nem sajnálják a közpénzt, hiszen nem az övék. Tolvaj banda!

'Hahaha! Poor try, at least 5 Fidesz trolls have already cracked this joke before you. But the Fidesz agitprop department pays for these comments as well, they don't care about the public money as it is not theirs. Thief gang!'

(16) [Varánusz 19092015]

Ha nem lennénk uniós tagok, te biztos nem itt trollkodnál, mert nem lenne rá pénze a kormánynak.

'If we weren't members of the [European] Union, you wouldn't be trolling here, as the government wouldn't have money for that'.

Examples (15) and (16) illustrate that Fidesz or the Hungarian government is believed to financially support trolling on these left-wing blogs. In Example (15), it is also assumed that Fidesz has an agitprop (agitation and propaganda) department that pays for trolling comments and uses public money for this purpose. As agitprop is strongly associated with the highly rejected (Soviet) Communism, it is implied that similarly to the Communist state parties, Fidesz is an immoral and corrupt party that tries to systematically manipulate the public and that trolling is part of its propaganda.

(17) [Varánusz 17072015]

Baszd meg, mielött kommentelnél tanulj meg helyesen írni. Bántja szememet a helyesírásod. Vagy a Fidesz trollképzöjében a helyesírás nem tantárgy?

'Fuck you, learn how to spell before you would comment. Your spelling is hurting my eyes. Or isn't spelling a subject in the Fidesz troll school?'

Finally, the poster mainly criticises the addressee's spelling in Example (17) but he also implies sarcastically that Fidesz has a troll school where the trolls are trained. 
The idea that trolls are trolling because they are employed by a political body has not been discussed in the literature. When this motive emerges, trolling is constructed as a financially and politically motivated and centrally organised collective activity while trolls are portrayed as unskilled and low-paid employees of low prestige who simply follow orders but do not necessarily support the political body that employs them.

\subsection{Assumed motive for trolling (5): Unspecified political affiliation}

One final recurring motive attributed to the trolls appears in those comments where posters indicate that others are trolling due to their political affiliation. However, it remains unspecified whether the trolls merely support a political body or work for it.

(18) [B1 22042015]

Hazug fidesztroll, felsorolnal par orszagot ami az utobbi 5 evben oldotta fel a magyarok elleni kvotakat?

'Lying Fidesz troll, could you list some countries that have abolished the quotas against Hungarians in the last five years?'

In Example (18), fidesz-is clearly a motivation-related element in the fidesztroll compound. However, it has two equally acceptable interpretations - that the addressee is a keen Fidesz supporter and thus, the attributed motive for trolling would be a particular political belief, or that he is trolling because Fidesz employs him as a troll. These two options are not presented as alternatives in the comment itself and thus, the nature of this political affiliation remains unclear and the way trolling and trolls are constructed is ambiguous.

Table 3 summarizes how linguistically marked motive attribution contributes to the discursive construction of trolling behaviour and identity.

Table 3. The discursive construction of trolling and trolls in the metapragmatic comments

\begin{tabular}{lll}
\hline Assumed motive & Trolling & Trolls \\
\hline Emotional reasons & $\begin{array}{l}\text { Emotionally motivated } \\
\text { individual behaviour }\end{array}$ & $\begin{array}{l}\text { Miserable individuals with } \\
\text { emotional problems }\end{array}$ \\
Financial gain & $\begin{array}{l}\text { Financially motivated } \\
\text { individual activity }\end{array}$ & $\begin{array}{l}\text { Rational but immoral } \\
\text { individuals }\end{array}$ \\
Political beliefs & $\begin{array}{l}\text { Ideologically motivated } \\
\text { individual activity }\end{array}$ & $\begin{array}{l}\text { Irrational political fanatics } \\
\text { Being employed by Fidesz } \\
\text { or the Hungarian } \\
\text { government }\end{array}$ \\
$\begin{array}{l}\text { Unspecified political } \\
\text { affiliation }\end{array}$ & $\begin{array}{l}\text { motivated and centrally } \\
\text { organised collective activity }\end{array}$ & $\begin{array}{l}\text { Employees who follow orders } \\
\text { Fut do not necessarily support }\end{array}$ \\
\hline
\end{tabular}


The analysis of Examples (1)-(18) demonstrated that linguistically marked motive attribution is a behaviour and identity building device since participants discursively construct trolling behaviour and identity by attributing motives to those they call trolls. Table 3 shows that depending on these motives, trolls and trolling are constructed in different ways. It is worth noting that financial gain, political beliefs, being employed by a political body and an unspecified political affiliation as motives for trolling have not been discussed in the literature. As these motives also entail different forms of constructing trolling, they also contribute to the wider academic study of how participants perceive trolling.

\section{Annotation of the troll motive comments}

The above-presented motives were used as descriptive categories to manually annotate the 123 troll motive comments in the corpus. Table 4 summarizes the tagset. It presents the tags themselves, the motives they mark, and some prototypical examples. With the exception of Example (19), the examples refer to those discussed in the previous section.

Table 4. The tagset that was used for annotating the comments

\begin{tabular}{|c|c|c|}
\hline Tag & Marked motive & Example \\
\hline motive_1 & Emotional reasons & $\begin{array}{l}\text { Examples (1)-(3) } \\
\text { e.g. Nem megy a pici blogja, hát trollkodik a lölköm } \\
\text { ('His little blog isn't too successful so he is trolling') }\end{array}$ \\
\hline motive_2 & Financial gain & $\begin{array}{l}\text { Examples (4)-(6) } \\
\text { e.g. pénzért trollkodsz ('you are trolling for money') }\end{array}$ \\
\hline motive_3 & Political beliefs & $\begin{array}{l}\text { Examples (7)-(10) } \\
\text { e.g. széljobbos troll ('far-right troll') }\end{array}$ \\
\hline motive_4 & $\begin{array}{l}\text { Being employed } \\
\text { by Fidesz or } \\
\text { the Hungarian } \\
\text { government }\end{array}$ & $\begin{array}{l}\text { Examples (11)-(17) and (19) } \\
\text { e.g. most neveztek ki a Miniszterelnökségen ügyeletes } \\
\text { trollkodónak ('you have been appointed now as troller } \\
\text { on duty at the Prime Minister's Cabinet Office') }\end{array}$ \\
\hline motive_4.1 & $\begin{array}{l}\text { Being sent by Fidesz } \\
\text { or the government } \\
\text { to troll }\end{array}$ & $\begin{array}{l}\text { Example (13) } \\
\text { e.g. egyre primitívebb gondolkodású egyedeket küldenek } \\
\text { trollkodni ('they are sending individuals with more and } \\
\text { more primitive thinking to troll') }\end{array}$ \\
\hline motive_4.2 & $\begin{array}{l}\text { Being told by Fidesz } \\
\text { or the government } \\
\text { how to troll }\end{array}$ & $\begin{array}{l}\text { Example (14) } \\
\text { e.g. A gazdád ezt mondta az eligazitáson balfasz } \\
\text { fidesztroll, hogy ezt kell hazudni a blogokon? ('Did your } \\
\text { master say at the briefing, dumbfuck Fidesz troll, that } \\
\text { you had to lie this on the blogs?') }\end{array}$ \\
\hline
\end{tabular}


Table 4. (continued)

\begin{tabular}{lll}
\hline Tag & Marked motive & Example \\
\hline motive_4.3 & $\begin{array}{l}\text { Being paid by Fidesz } \\
\text { or the government } \\
\text { to troll }\end{array}$ & $\begin{array}{l}\text { Example (15)-(16) and (19) } \\
\text { e.g. az ilyen hozzászólásokért is fizet a fideszes agitprop } \\
\text { osztály ('the Fidesz agitprop department pays for these } \\
\text { comments as well') }\end{array}$ \\
motive_4.4. & $\begin{array}{l}\text { Being trained by Fidesz } \\
\text { or the government for } \\
\text { trolling }\end{array}$ & $\begin{array}{l}\text { Example (17) } \\
\text { e.g. a Fidesz trollképzőjében a helyesírás nem tantárgy? } \\
\text { ('isn't spelling a subject in the Fidesz troll school?') }\end{array}$ \\
motive_5 & $\begin{array}{l}\text { Unspecified political } \\
\text { affiliation }\end{array}$ & Example (18) \\
\hline
\end{tabular}

The most important tags are motive_1, motive 2 , motive_3, motive_4, and motive $\_$, which represent the five main motives for trolling discussed above. Motive_4.1, motive_4.2, motive_4.3 and motive_4.3 are subcategories within the broad motive of being employed by Fidesz or the Hungarian government (motive_4). I used these four subcategories as the qualitative analysis demonstrated that motive_ 4 has four clearly identifiable components. Consequently, I used these additional four tags only together with motive_4. For instance, motive_4 and motive_4.3 together mean that it is explicitly stated in the comment that the addressee is trolling both because Fidesz or the Hungarian government employs and pays him. On the other hand, those comments in which the poster suggests that the alleged troll is employed by Fidesz or the government but it has not been made explicit that they pay for trolling were provided with only motive_4. This distinction has been made because the study focuses on linguistically marked motivation attribution.

Motive_1, motive_2, motive_3, motive_4, and motive_5 were not used as mutually exclusive tags as I found comments, e.g. Example (19), where posters mentioned several motives.

(19) [ÖV 18092015]

Hagyd a trollt. Szerencsétlen alak, tele bizonytalansággal, félelemmel és kudarccal, amit itt és így próbál meg (túl)kompenzálni. Persze, lehet, hogy tévedek, és egyszerüen megdobták néhány rugóval a kormánypropaganda-keretböl.

'Leave the troll alone. He is a miserable guy filled with uncertainty, fear and failure that he is trying to (over)compensate for here this way. Of course, it's also possible that I'm wrong and he gets some money from the government propaganda budget.'

In Example (19), the poster first assumes that the addressee is trolling because of emotional reasons, such as uncertainty, fear, a sense of failure and the desire to somehow compensate for these feelings. However, the poster also suggest that the addressee might be trolling because he is paid by the government to do so. Both 
motives are explicitly discussed and therefore, this comment was tagged with motive_1, motive_4 and motive_4. 3 as well.

Table 5 presents the identified twelve $n$-grams of ${ }^{\star}$ troll $^{\star}{ }^{*}$ that mark a motive attributed to trolls. If a comment included a listed n-gram, it was provided with the tag in the marked motive column.

Table 5. The n-grams of ${ }^{\star}$ troll $^{\star}$ that mark a motive attributed to trolls

\begin{tabular}{|c|c|c|}
\hline N-gram & Translation & Motive tag \\
\hline fizetett troll(kodás) & 'paid troll(ing)' & motive_2 \\
\hline pénzért trollkodsz/trollkodik & 'you are/he is trolling for money' & motive_2 \\
\hline (agymosott) fidióta troll & '(brainwashed) fidiot troll' & motive_3 \\
\hline neonáci troll & 'neo-Nazi troll' & motive_3 \\
\hline szélsőjobbos (örült) troll & 'far-right (crazy) troll' & motive_3 \\
\hline fidesz(nek) trollja(i) & 'troll(s) of the Fidesz' & motive_4 \\
\hline (fideszes) agitprop bértroll & '(Fidesz) agitprop wage troll' & motive_4, motive_4.3 \\
\hline fideszes bértrollkommandó & 'Fidesz wage troll commando' & motive_4, motive_4.3 \\
\hline fideszmaffia bértrollja(i) & 'wage troll(s) of the Fidesz mafia' & motive_4, motive_4.3 \\
\hline fizetett fidesztroll & 'paid Fidesz troll' & motive_4, motive_4.3 \\
\hline fizetett fideszes troll & 'paid Fidesz troll' & motive_4, motive_4.3 \\
\hline kormányzati bértroll & 'governmental wage troll' & motive_4, motive_4.3 \\
\hline
\end{tabular}

The syntactic analysis reveals that the collected $\mathrm{n}$-grams are mostly noun phrases in which the head words are word forms of troll and the modifiers (e.g. fizetett ('paid'), szélsőjobbos ('far-right')) indicate the assumed motives for trolling.

Table 6 displays the results of the quantitative analysis. It presents the number of those comments that were provided with a particular motive-related tag. Note that as one comment could receive multiple tags, the sum of the percentages in the same column is not necessarily $100 \%$.

Table 6. The number of comments provided with a particular motive-related tag

\begin{tabular}{lcccc}
\hline Tag & $\begin{array}{c}\mathrm{B} 1 \\
(\mathbf{1 0 0 \%}=\mathbf{6 4})\end{array}$ & $\begin{array}{c}\text { ÖV } \\
(\mathbf{1 0 0 \%}=\mathbf{1 7})\end{array}$ & $\begin{array}{c}\text { Varánusz } \\
(\mathbf{1 0 0 \%}=\mathbf{4 2})\end{array}$ & $\begin{array}{c}\text { Overall } \\
(\mathbf{1 0 0 \%}=\mathbf{1 2 3})\end{array}$ \\
\hline motive_1 & $1(1.6 \%)$ & $4(23.5 \%)$ & $5(11.9 \%)$ & $10(8.1 \%)$ \\
motive_2 & $17(26.6 \%)$ & $\mathbf{3 ( 1 7 . 6 \% )}$ & $\mathbf{8}(\mathbf{1 9 \% )}$ & $\mathbf{2 8}(\mathbf{2 2 . 8 \% )}$ \\
motive_3 & $10(15.6 \%)$ & $4(23.5 \%)$ & $1(2.4 \%)$ & $15(12.2 \%)$ \\
motive_4 & $23(35.9 \%)$ & $7(41.2 \%)$ & $26(61.9 \%)$ & $56(45.5 \%)$ \\
motive_4.1 & $2(3.1 \%)$ & $0(0 \%)$ & $7(16.7 \%)$ & $9(7.3 \%)$ \\
motive_4.2 & $2(3.1 \%)$ & $0(0 \%)$ & $4(9.5 \%)$ & $6(4.9 \%)$ \\
motive_4.3 & $17(26.6 \%)$ & $4(23.5 \%)$ & $7(16.7 \%)$ & $28(22.8 \%)$ \\
motive_4.4 & $0(0 \%)$ & $0(0 \%)$ & $2(4.8 \%)$ & $2(1.6 \%)$ \\
motive_5 & $15(23.4 \%)$ & $0(0 \%)$ & $2(4.8 \%)$ & $17(13.8 \%)$ \\
\hline
\end{tabular}


The numbers show that motive_4, i.e. being employed by Fidesz or the Hungarian government, is the most frequently mentioned assumed motive for trolling. It is attributed to participants in 56 comments (45.5\%) out of 123 . This suggests that trolling is predominantly constructed as a financially and politically motivated collective activity organised by Fidesz or the Hungarian government. In turn, trolls are mainly identified as unskilled and low-paid Fidesz or governmental employees of low prestige who may not necessarily support Fidesz or the Hungarian government. In half of the comments where this main motive appears, it is also accompanied by the linguistically marked assumption that Fidesz or the Hungarian government provides funding for trolling (motive_4.3).

The second most prominent assumed motive for trolling is financial gain (motive_2). The participants suggest in $22.8 \%$ of the comments that other participants are trolling because they are paid for it. The other two motives, i.e. political beliefs (motive_3) and various emotional reasons (motive_1) are attributed to trolls only in $12.2 \%$ and $8.1 \%$ of the comments, respectively. This suggests that although trolling is usually described as an emotionally motivated individual behaviour in the academic literature, participants in this dataset only rarely attribute emotional motives to those they call trolls.

Note that it would be meaningless to test whether the difference between these numbers is statistically significant. This is not because the samples are too small but because significance testing assumes that the datasets we compare are statistically representative samples of wider populations and consequently, if we find a statistically significant difference between them, we can conclude that this observed difference not only applies to the examined samples but also exists between the wider populations. However, the examined 123 comments are not statistically representative samples of any wider populations. For instance, we cannot claim that the investigated comments constitute a statistically representative sample of all troll motive comments on the considered blogs. Therefore, the observed differences only apply to the examined comments and they cannot be extrapolated.

\section{Conclusions}

The main findings of this study are as follows. Firstly, posters on these left-wing Hungarian political blogs attribute five motives to the alleged trolls, including emotional reasons, financial gain, political beliefs, being employed by Fidesz or the Hungarian government, and an unspecified political affiliation. Thus, although the literature on trolling mainly focuses on emotional reasons for trolling, in practice, depending on the context, participants also ascribe other motives to the alleged trolls. In fact, not emotional reasons but financial gain and being employed by 
Fidesz or the Hungarian government are the dominant assumed motives for trolling in this corpus.

Secondly, the n-gram analysis revealed that participants mainly use adjectives before TROLL to attribute motives to the alleged trolls. However, the fact that no n-grams marking an emotional motive for trolling have been identified indicates that while n-gram analysis can be effectively used to make the annotation process more transparent and systematic, the qualitative-interpretative analysis of the comments remains essential when identifying the different motives attributed to trolls.

Thirdly, depending on the attributed motives, trolling and trolls are constructed in different ways. Most papers suggest that trolling is an emotionally motivated individual behaviour. However, in these threads, trolling is not only constructed this way but dominantly as a financially/politically motivated and often centrally organised collective activity. Similarly, trolls are dominantly identified as low-paid employees of Fidesz or the Hungarian government and not as troubled individuals with emotional problems. This suggests that the specific ways in which trolling and trolls are constructed are strongly context-dependent. The reason why trolling is dominantly constructed as a financially/politically motivated and often organised activity is most likely the online political discourse these threads belong to. The key topic of this discourse is corruption and the organised manipulation of the public through the media in Hungary. Consequently, it is not surprising that trolling is chiefly constructed in the analysed comments in line with the discourse these comments relate to.

Fourthly, a local conspiracy theory has been developed around trolling on the investigated blogs. The comments repeatedly suggest that Fidesz or the Hungarian government secretly employs trolls. Whilst the posters offer no evidence to support this, it is a relatively well-established belief on the examined blogs as apart from those who are called trolls, no one actively disagrees with the idea that Fidesz or the government employs trolls and sends them to left-wing blogs. However, the absence of linguistically marked disagreement does not necessarily mean that all participants share this belief.

Fifthly, by suggesting that Fidesz or the Hungarian government employs trolls and sends them to opposition blogs, posters construct Fidesz as an autocratic and corrupt state party that systematically tries to manipulate the public. In this framework, trolling becomes part of the Fidesz and government propaganda. In turn, trolls are depicted as party workers who simply follow orders without necessarily supporting Fidesz and the government or actually believing in what they are saying - rather, their main motive for trolling is financial in nature. The assumption that Fidesz or the government sends trolls to the examined blogs and pays them for their activity also implies that these blogs and their comment threads have political relevance and influence. Thus, when participants call other participants paid Fidesz 
trolls, they also imply that their own comments and the blog where they are posting them are of actual political importance.

Finally, from a broader theoretical and methodological perspective, the main implication of this study is that linguistically marked mental state attribution is a behaviour- and identity-building device that strongly contributes to the discursive construction of folk concepts associated with discursive behaviour, such as trolling. Thus, it should be taken into account when investigating how participants interpret other participants' utterances in metapragmatic comments.

\section{References}

Anthony, Laurence. 2016. AntConc (Version 3.4.4) [Computer Software]. Tokyo, Japan: Waseda University. Available from http://www.laurenceanthony.net/

Baker, Paul. 2001. "Moral Panic and Alternative Identity Construction in Usenet." Journal of Computer-mediated Communication (7) 1.

Baker, Paul. 2006. Using Corpora in Discourse Analysis. London: Continuum.

Balconi, Michaela. 2010. "Intentions and Communication: Cognitive Strategies, Metacognition and Social Cognition.” In Neuropsychology of Communication, ed. by Michaela Balconi, 159-176. London/New York: Springer. https://doi.org/10.1007/978-88-470-1584-5_9

Binns, Amy. 2012. "Don't Feed the Trolls! Managing Troublemakers in Magazines' Online Communities." Journalism Practice 6 (4): 547-562.

https://doi.org/10.1080/17512786.2011.648988

Brezina, Vaclav, Tony McEnery, and Stephen Wattam. 2015. "Collocations in Context: A New Perspective on Collocation Networks." International Journal of Corpus Linguistics 20 (2): 139-173. https://doi.org/10.1075/ijcl.20.2.01bre

Buckels, Erin E., Paul D. Trapnell, and Delroy L. Paulhus. 2014. “Trolls Just Want to Have Fun.” Personality and Individual Differences 35 (67):97-102. https://doi.org/10.1016/j.paid.2014.01.016 Cheng, Justin et al. 2015. "Antisocial Behavior in Online Discussion Communities." Proceedings of ICWSM 2015. http://arxiv.org/abs/1504.00680 (Date of access: 25 February 2017)

Cienki, Alan. 2007. "Frames, Idealized Cognitive Models, and Domains." In The Oxford Handbook of Cognitive Linguistics, ed. by Dirk Geeraerts, and Hubert Cuyckens, 170-187. Oxford: Oxford University Press

Culpeper, Jonathan, and Claire Hardaker. 2016. “Pragmatics.” In Triangulating Methodological Approaches in Corpus-linguistic Research, ed. by Paul Baker, and Jesse Egbert, 124-137. New York/London: Routledge.

Donath, Judith S. 1999. "Identity and Deception in the Virtual Community." In Communities in Cyberspace, ed. by Peter Kollock, and Marc A. Smith, 27-58. London/New York: Routledge Fichman, Pnina, and Madelyn Rose Sanfilippo. 2015. “The Bad Boys and Girls of Cyberspace: How Gender and Context Impact Perception of and Reaction to Trolling." Social Science Computer Review 33 (2): 163-180. https://doi.org/10.1177/0894439314533169

Galán-García, Patxi et al. 2014. "Supervised Machine Learning for the Detection of Troll Profiles in Twitter Social Network: Application to a Real Case of Cyberbullying." In Proceedings of International Joint Conference SOCO'13-CISIS'13-ICEUTE'13, ed. by Álvaro Herrero et al., 419-428. New York: Springer. https://doi.org/10.1007/978-3-319-01854-6_43 
Golder, Scott A., and Judith S. Donath. 2004. "Social Roles in Electronic Communities." Paper presented at the Association of Internet Researchers (AoIR) Conference Internet Research 5.0, 19-22 September 2004. Brighton, England. 1-25.

Greaves, Chris, and Martin Warren. 2010. “What Can a Corpus Tell Us about Multi-word Units?” In The Routledge Handbook of Corpus Linguistics, ed. by Anne O’ Keeffe, and Michael McCarthy, 212-226. London/New York: Routledge. https://doi.org/10.4324/9780203856949.ch16

Hardaker, Claire. 2010. "Trolling in Asynchronous Computer-mediated Communication: From User Discussions to Academic Definitions." Journal of Politeness Research. Language, Behaviour, Culture 6 (2): 215-242.

Hardaker, Claire. 2013. ““'Uh....not to be nitpicky,,,,,but...the past tense of drag is dragged, not drug." An Overview of Trolling Strategies." Journal of Language Aggression and Conflict 1 (1): 58-86. https://doi.org/10.1075/jlac.1.1.04har

Hardaker, Claire. 2015. "'I refuse to respond to this obvious troll': An Overview of Responses to (Perceived) Trolling." Corpora 10 (2): 201-229. https://doi.org/10.3366/cor.2015.0074

Haugh, Michael, and Kasia M. Jaszczolt. 2012. "Speaker Intentions and Intentionality." In The Cambridge Handbook of Pragmatics, ed. by Keith Allan, and Kasia M. Jaszczolt, 87-112. Cambridge: Cambridge University Press. https://doi.org/10.1017/CBO9781139022453.006

Herring, Susan C. et al. 2002. “Searching for Safety Online: Managing „Trolling” in a Feminist Forum.” The Information Society 18 (5): 371-384. https://doi.org/10.1080/01972240290108186

Herring, Susan C., Dieter Stein, and Tuija Virtanen (eds). 2013. Pragmatics of Computer-Mediated Communication. Berlin/New York: Mouton De Gruyter. https://doi.org/10.1515/9783110214468

Hopkinson, Christopher. 2013. "Trolling in Online Discussions: From Provocation to Communitybuilding." Brno Studies in English 39 (1): 5-25. https://doi.org/10.5817/BSE2013-1-1

Hübler, Axel. 2011. "Metapragmatics." In Foundations of Pragmatics, ed. by Wolfram Bublitz, and Neal R. Norrick, 107-136. Berlin/New York: Mouton de Gruyter. https://doi.org/10.1515/9783110214260.107

Jenkins, Richard. 2014. Social Identity. London/New York: Routledge.

Langlotz, Andreas. 2010. "Social Cognition." In Interpersonal Pragmatics, ed. by Miriam A. Locher, and Sage L. Graham, 167-204. Berlin/New York: Mouton de Gruyter.

Lockard, Matthew. 2014. "Implication and Reasoning in Mental State Attribution: Comments on Jane Heal's Theory of Co-cognition.” Philosophical Psychology 27 (5): 719-734. https://doi.org/10.1080/09515089.2012.730040

McCosker, Anthony. 2014. "Trolling as Provocation: YouTube's Agonistic Publics." Convergence: The International Journal of Research into New Media Technologies 20 (2): 201-217. https://doi.org/10.1177/1354856513501413

Morrissey, Lochlan. 2010. "Trolling Is an Art: Towards a Schematic Classification of Intention in Internet Trolling." Griffith Working Papers in Pragmatics and Intercultural Communications 3 (2): 75-82.

Noveck, Ira. 2010. "Inferential Comprehension.” In The Routledge Pragmatics Encyclopedia, ed. by Louise Cummings, 220-222. London/New York: Routledge.

Ortega, Javier F. et al. 2012. "Propagation of Trust and Distrust for the Detection of Trolls in a Social Network." Computer Networks 56 (12): 2884-2895.

https://doi.org/10.1016/j.comnet.2012.05.002

Özsoy, Duygu. 2015. “Tweeting Political Fear: Trolls in Turkey.” Journal of History School 8 (22): 535-552. https://doi.org/10.14225/Joh750 
Petykó, Márton. 2013. “Az internetes troll mint identitás kialakítása politikai blogok diskurzusaiban [Construction of internet troll as an identity in the discourses of political blogs]." Magyar Nyelvör 133 (3): 274-313.

Postmes, Tom, Russel Spears, and Martin Lea. 2000. “The Formation of Group Norms in Computer-Mediated Communication." Human Communication Research 26 (3): 341-371. https://doi.org/10.1111/j.1468-2958.200o.tboo761.x

Shachaf, Pnina, and Noriko Hara. 2010. "Beyond Vandalism: Wikipedia Trolls." Journal of Information Science 36 (3): 357-370. https://doi.org/10.1177/0165551510365390

Tanskanen, Sanna-Kaisa. 2007. "Metapragmatic Utterances in Computer-mediated Interactions”. In Metapragmatics in Use, ed. by Axel Hübler, and Wolfram Bublitz, 87-106. Amsterdam: John Benjamins. https://doi.org/10.1075/pbns.165.07tan

Thacker, Scott, and Mark D. Griffiths. 2012. "An Exploratory Study of Trolling in Online Video Gaming." International Journal of Cyber Behaviour, Psychology and Learning 2 (4): 17-33. https://doi.org/10.4018/ijcbpl.2012100102

Tomasello, Michael et al. 2005. "Understanding and Sharing Intentions: The Origins of Cultural Cognition." Behavioral and Brain Sciences 28 (5): 675-691. https://doi.org/10.1017/S0140525X05000129

Utz, Sonja. 2005. “Types of Deception and Underlying Motivation. What People Think." Social Science Computer Review 23 (1): 49-56. https://doi.org/10.1177/0894439304271534

Verschueren, Jef. 1999. Understanding Pragmatics. New York: Oxford University Press.

Verschueren, Jef. 2000. “Notes on the Role of Metapragmatic Awareness in Language Use." Pragmatics 10 (4): 439-456. https://doi.org/10.1075/prag.10.4.02ver

Wright, Rex A. 2016. "Motivation Theory Essentials: Understanding Motives and Their Conversion into Effortful Goal Pursuit.” Motivation and Emotion 40 (1): 16-21.

\section{Author's address}

Márton Petykó

Department of Linguistics and English Language

Lancaster University

Lancaster LA1 4YL

United Kingdom

m.petyko@lancaster.ac.uk 